原著論文

\title{
体感音楽聴取方法の質的分析と量的分析による感性評価
}

\author{
井手口 健
}

東海大学 産業工学部

\author{
Sensibility Evaluation using Qualitative Analysis and Quantitative Analysis \\ for Bodily Sensation Music Listening Method
}

Tsuyoshi IDEGUCHI

Tokai University, 9-1-1 Toroku, Higashi-ku, Kumamoto city, Kumamoto 862-8652, Japan

\begin{abstract}
The sensibility evaluation through the quantitative analysis has not yet provided an enough data concerning an appeal of essential charm and a concrete design. Therefore, we have used a method which covers both qualitative and quantitative analysis to develop a "bodily sensation music listening method." At first, we have collected live impression words from our subjects who are listening to bodily sensation music, and then we have deciphered the meanings and structures of those words and classified them by using KJ method. Thus, we have made clearer the strength and weakness peculiar to this listening method. Next, we have carried out factor analysis for the live impression words by using SD method. Thus, we have extracted the impression structures peculiar to the bodily sensation music listening method more in detail, such as sound image factor, bodily sensation factor and the feeling of the subject by combining qualitative analysis with quantitative one. Finally, we have discussed the reason why such feelings of the subject was provided based on the results obtained by our method using both quantitative and qualitative analysis.
\end{abstract}

Keywords : Bodily sensation music listening method, Qualitative data, Quantitative data, KJ method, Sensibility evaluation, objective evaluation

\section{1. 本研究の背景と目的}

筆者等は，楽曲を耳で聴くと同時に楽器音に応じた振動を ダイレクトに取り出し体に付与することで魅力的に音楽を楽 しむ方法の検討を行っている [1-4]，その実現システムとし て，複数チャンネル録音された再生音を遠方スピーカーから 聴きながら，特定チャンネルの至近音と振動触覚を付与する 体感音楽聴取方法を開発している [3]，図 1 は2チャンネル 用の体感音楽聴取法を示している。このシステムの心臓部は, 至近音と振動触覚付与デバイスである。 アコースティックギ ターの共鳴箱が空気振動を体前面に付与する媒体として適し ていることに着目し，アコースティックギターの共鳴箱の開 口にスピーカーから音を吹き込む手法を採った. 具体的には, アコースティックギターのサウンドホールに市販のスピー カー（FOSTEX株式会社製，FE127E）を取り付け，サウン ドホール内にスピーカー再生音による空気振動を注入する. こうすることにより，この装置を抱え音楽を再生させた時 に，至近音を聴きながらギター本体の振動を体前面に感じる 体感聴取が可能となる。加えて, 他チャンネルの楽曲音は遠 方スピーカから聴取するシステムである.

この聴取方法に対して，筆者等は 2 種類の感性評価を実施 し，その有効性を明らかにしてきた。その一つは, シェッフェ の一対比較法であり, 音の広がり感, 音の奥行き感, 魅力度, 演奏者感を確認項目とし, 体感音楽聴取法は通常の聴取方法 に比べて良好であるとの結果であった。二目は一般的に視
聴覚コンテンツを視聴する際に使用される印象語対による SD法を用いた因子分析である。共通因子として臨場感因 子, 輪郭感因子，明暗感因子，美的因子が抽出され，体感音 楽聴取法は臨場感因子と輪郭感因子の得点が高いとの結論を 得た。これらの結果は論文 [3]としてまとめた

しかし，上記研究では，抽出された共通因子が，音楽聴 取時の一般化した印象構造マップの中での体感音楽の量的 分析を行ったものであり, 概観的な結論となっている.また, 一対比較法で使った印象語も筆者等が数種類意図的に使った ものに過ぎず唐突の感が否めない。すなわち, このシステ ムの魅力や改善点を十分に伝えきった結論になっていない.

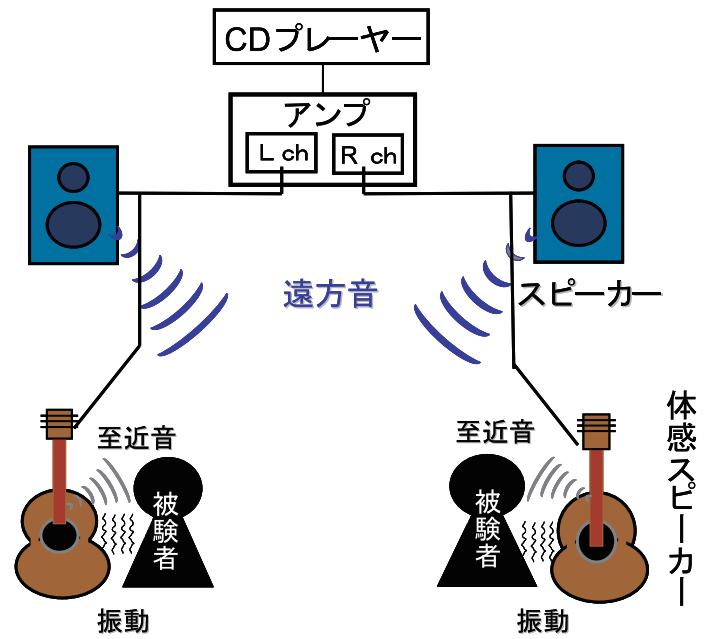

図1 ステレオ音源を用いた体感音楽聴取方法 
すなわち, 従来の多変量解析を用いた量的分析では, 感性 ロスが発生しているのではないかと思われる $[5]$ ，そこで, 本稿では, 体感音楽聴取法の魅力・ 尔点を深く掘り下げるた め, 質的分析も交えて再度検討することとした. 本論文では, まず，質的分析を導入することにより，一般的ではなくこの 音楽聴取方法に特有な生の感性ワードを抽出することとし た. 次に, これらの感性ワードに多変量解析という量的分析 を加え, 体感音楽聴取方法に特有な感性空間を構築すること とした，こうすることにより，筆者らが提案している体感音 楽聴取方法の魅力と課題をより染く抽出できるかどうかを検 討した。

\section{2. 質的分析と量的分析を組み合わせた評価}

上述したように, 音や音楽を聴取する場合の一般的な印象 語対を用いた多変量解析で, 新たに考案した体感音楽聴取法 のアピールを行うには限界がある。 そこで, 筆者らは質的分 析と量的分析を組み合わせて評価することにした，具体的に は，体感音楽の被験者に感じたことを自由に記述してもら い，その断片的な記述内容を $\mathrm{KJ}$ 法を用いて体系化すること とした。この段階で, 提案している体感音楽聴取方法が有す る独特な魅力と課題が浮かび上がってくると考えられる。さ らに, そこで抽出された体感音楽聴取時に得られる印象語対 に対してSD法による量的主観評価を実施し，因子分析に よって背後に隠されている印象構造を抽出し, その構造を構 成する共通因子を体感音楽聴取法の評価ツールとして利用 し，質的分析結果で補間する方法を考えた。

\section{1 体感音楽聴取方法}

本論文に示す実験で被験者に供される体感音楽聴取方法お よび通常ステレオ聴取方法を説明する.

ステレオ録音された音楽を再生装置を用いて体感聴取する 方法は次の通りである。図1に示すように，音楽がステレオ 録音された CD $\mathrm{CD}$ プレーヤーとそれに接続されたパワー アンプで再生する. パワーアンプは2システムのメインスピー カー端子を有しているものを使い, 一つのメインスピーカー 端子にLチャンネル用とRチャンネル用スピーカーを接続 L, もう一つのメインスピーカー端子にLチャンネル用体感 スピーカーと Rチャンネル用体感スピーカーを接続する.

このシステムを用いて 2 名の聴取者が音楽を鑑賞する。

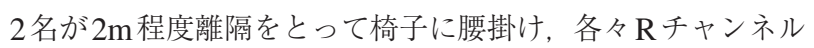
用体感スピーカーと L千ャンネル用体感スピーカーを抱える.

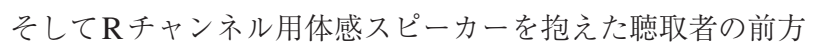

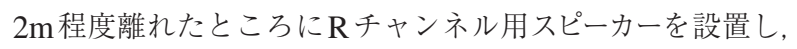
Lチャンネル用体感スピーカーを抱えた聴取者の前方 $2 \mathrm{~m}$ 程 度離れたところにLチャンネル用スピーカーを設置している。

この状態で，CDにステレオ録音された音楽を再生させる

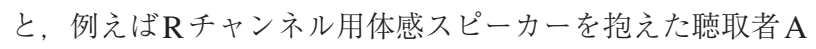
は, Rチャンネルで再生されている楽器音を, 体感スピーカー からの至近音と Rチャンネル用スピーカーからの遠方音とで
作られる音像位置から発せられているように聴くと同時に, 体感スピーカーからその楽器音に応じた振動を受けることに なる，さらにこの聴取者 $\mathrm{A} に は ， \mathrm{~L}$ チャネル用スピーカー と Lチャンネル用体感スピーカーから再生されている楽器音 は遠方音として聴こえることになる。すなわち，聴取者 Aは $\mathrm{R}$ チャンネルで再生された楽器音による体感刺激を強く受け ながら楽器演奏全体音を聴くことになる.

また，この視聴方法は一人ででも可能である。この場合, Lチャンネル用体感スピーカーは，抱く人がいなくても L チャンネル用スピーカーと同様に遠方音を付与するスピー カーとして機能することになる。 なお，本論文において，通

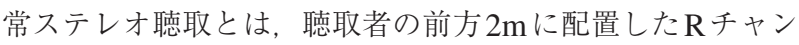
ネル用スピーカーと Lチャンネル用スピーカーから再生され る音を聴取する方法を言う.

\subsection{KJ法による質的分析}

筆者らが提案する体感聴取法は被験者にとって初めて経験 するものである。したがって感じた生の印象を漏らさず採集 することが質的分析の最初のステップであると考えた。この ようにして採集された印象語は断片的なデータの羅列となる ので, ここから体感音楽聴取法が持つ特有の性質や得られる 印象の構造を体系化された表現でまとめることが必要であ り，そのためにKJ法を用いることとした，KJ法とは，無秩 序で雑然とした定性デー夕 (事実, 意見, アイデア) 群を, 一度カードや付箋紙などに分解し，これを人間の直観力を用 いて図解・文章に統合することで, 意味や構造を読み取り, まとめていく方法である [6].

\section{（1）自由記述による印象の採集}

男女 30 名の大学生に, 通常ステレオ聴取と体感音楽聴取 を行ってもらい, 体感音楽聴取した時の印象を A4 用紙に自 由に記述してもらった。楽器演奏経歴は不問とした。被験 曲は, ギターやベース, バスドラムといった振動を抽出し やすい, ジャンルの異なった 3 曲とした. アコースティック ギター・デュオ曲であるゴンチチの「枯葉」, ポピュラー音 楽であるジプシーキングスの「インスピレーション」, およ びジャズ曲である渡辺貞夫の「カリフォルニアシャワー」 である。

本実験には，2.1節で説明した体感音楽聴取方法と通常ス テレオ聴取方法を実施し，二人づつ楽曲を被験する方法を 採った。一つの楽曲に対して, 通常ステレオ聴取で約 1 分間, 引き続き体感音楽聴取で約 1 分間聞いてもらい，後者を聞い てもらった時の印象をアンケート用紙に自由に記述しても らった。

これまで，体感音楽の実験で使用してきた「美しい」 「面白い」などの一般的な印象語に比べ，今回の実験で得た 48個の印象語は，よく体感音楽の性質を表している。それ に加えて，それらの印象語に比べ，何に対して「美しい」な のか「面白い」なのかが具体的な表現になり, わかりやすく なったといえる 
また，それぞれの被験者の音楽に対する感じ方，考え方の 多様さがこの 48 個の印象語に現れているように思われる.

\section{（2）KJ法による印象の体系化}

体感音楽を表す48個の印象語はこのままでは断片的な デー夕に過ぎない，その断片的なデー夕の体系を探る必要が ある。そこで，KJ法という問題解決の手法を利用し検討す る．混在したデー夕を KJ 法で整理して属性に分類すること でデータの体系を把握し，新しい視点から見解を引き出す.

まず，体感音楽を表す48個の印象語を，内容の近しいも のは省いて45個に整理した。

KJ法での検討により図 2 に示すように分類した。45個の 印象語を「音楽の䨌囲気」,「音像」,「意識」,「音の質感」, 「体感」,「ストレス」の大きく6つの属性に分類した。性質 がどの属性にもあてはまらないと判断したものは,「その他」 に記載している。これによって, 体感音楽を現す断片的なデー タでしかなかった印象語の性質が明らかになった。

次に, KJ法で整理し分類した結果を体系化し文章化する。 図3 は分類した属性から文章化する時点で体系化した視点で ある。この図に基づいて文章化すると，「ギターやベースな どの楽器音の生々しさが強調され (音質), いろいろな楽器 音が自分の周りの様々な場所から聴こえ (音像), ギターや ベースなど特定の楽器の音を弦の振動を体前面で捕らえなが ら懐で聴くと, 体が打ち震えたり内臓に音が染み込むような 感覚にとらわれる（体感）。これらの3つの要素が, 他の演 者が他の楽器を弾いている中で自分も演奏者になった感じで セッションをしながら音楽を聴いているという感じにさせて くれる，また，当然のことながら，この3つの要素は，音楽
を乗りの良いものとして, さらに臨場感あふれ迫力あるもの として生きた音楽としての雲囲気を持たせている. しかし， 一方, この3つの要素は, 今まで聴いてきた音楽の聴取方法 と異なる違和感や聴覚だけでなく触覚も動員することによる 緊張感がストレスを感じさせる可能性もある.」となろう.

このように, 我々が提案している体感音楽聴取方法の長所 と短所を体系的に整理できている。前論文で実施した主観評 価に比べて, 本聴取方法特有な魅力, 今後の展開の方向性, 改善の余地の所在などが抽出できていると思われる。図2に 分類した「その他」は体感音楽を現すには異質な印象語であ り，「ストレス」から派生したものではないかと考える。

\subsection{SD法による量的分析}

前節の質的分析のために抽出された印象語を使って SD法 による量的主観評価実験を行い，これらの印象語の背後にあ

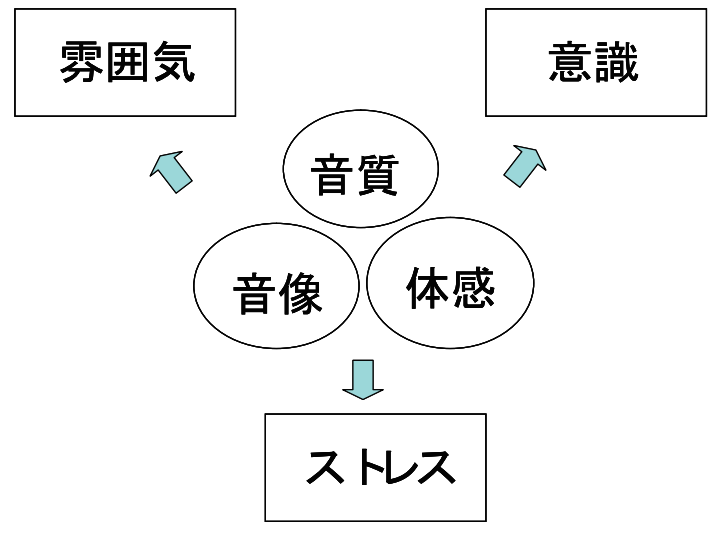

図3 ストーリーの文章化の視点（KJ法）

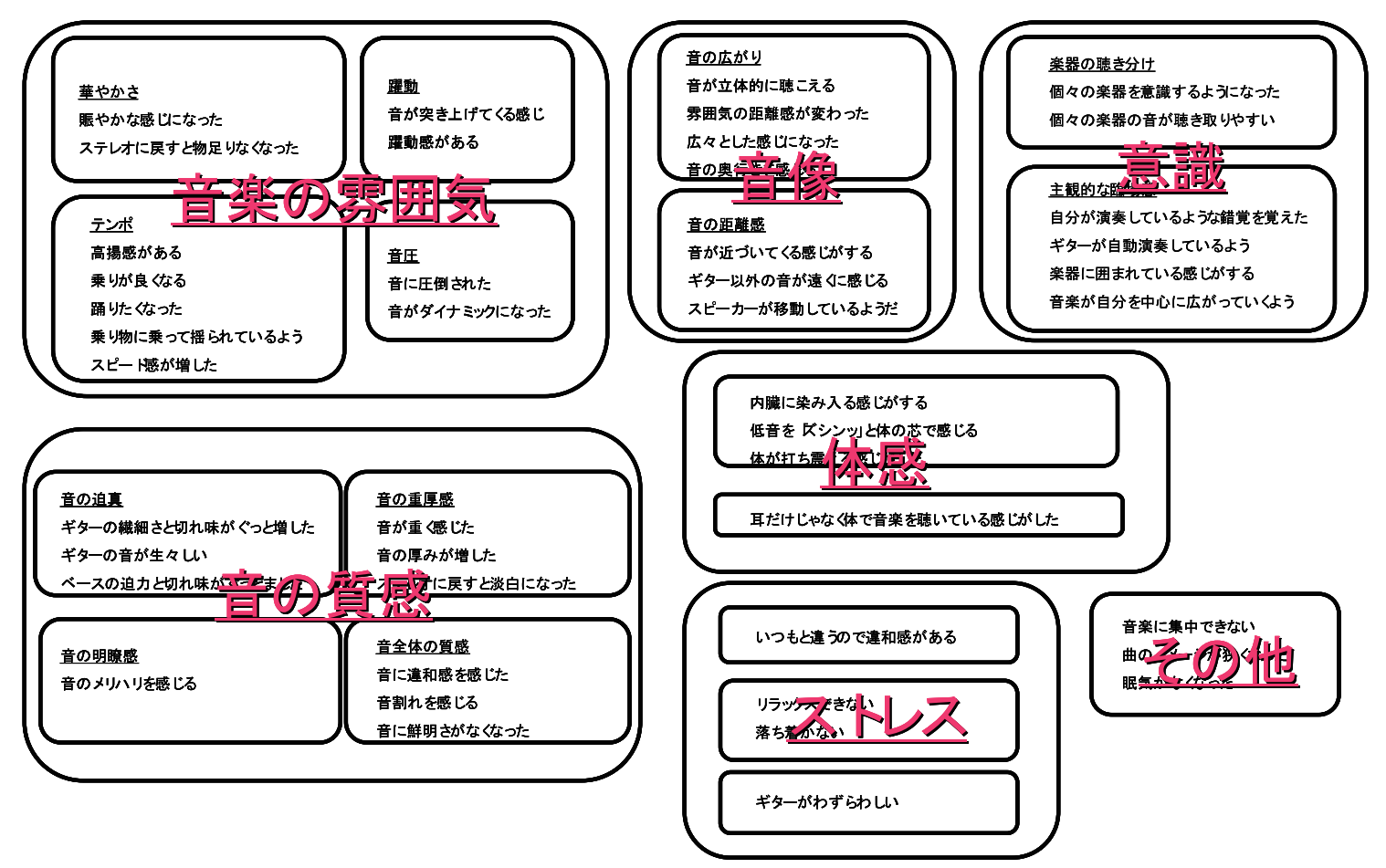

図2 質データのグループ化（KJ法） 
る共通因子を探るために因子分析 [7] を行った，文献 [3] が, 視聴覚コンテンツを視聴するときの印象を沉用的に使わ れる印象語対 [8] を使用しているのに対し, ここでは新た な音楽聴取方法によって感じられた独自の印象語対を使用し ている、こうすることにより, 感性ロスをできるだけ抑えて, 体感音楽独自の印象構造を量的分析手法を使って得られるの ではないかと考えた。

\section{（1）実験方法}

第3 章で, 分類の際に使用した45個の印象語を, 印象語 対の形式にした，そして，内容の近しいもの同士まとめて 39個の印象語対とした。また，印象語を短縮表現した。こ れは，被験者への負担を僅かでも軽減させるためである。

被験者は 20 歳代前半の男女 10 名とし, 楽器演奏経歴は不 問とした。披験楽曲は，ギターやベース，バスドラムといっ た振動を抽出しやすい, ジャンルの異なった 3 曲とした。 すなわち、アコースティックギター曲であるゴンチチの 「枯葉」, サーフミュージックである dick dale \& his del-tones の misirlou, ジャズ曲である渡辺貞夫のカリフォルニアシャ ワーの3曲である

本実験には，2.1節で説明した体感音楽聴取方法と通常ス テレオ聴取方法を実施し, 二人づつ楽曲を被験する方法を 採った。一つの楽曲に対して, 通常ステレオ聴取で約 1 分間, 引き続き体感音楽聴取で約 1 分間聞いてもらい，後者を聞い てもらった時の印象をアンケート用紙に記述してもらった。

被験者に被験前に提示した説明は,「今から 2 回曲を聴い てもらいます。最初に通常のステレオ音楽を聴いてもらい, 同じ音楽をこの装置を抱えて聞いてもらいます。この装置を 抱えて聴いた音楽の印象をアンケート用紙に答えてくださ い.」とした.

アンケート用紙には,「圧倒される一圧倒されない」,

「迫力がある一迫力がない」といったように，表 1 に示した 印象語と逆の印象語の対を39種類用意し, 各対を7段階に 区分し，被験者にその印象を感じた位置に○印をつけても らった。その結果を，表1に記述した印象語を感じる側を+ として, +3から-3までの点数をつけて数值データとして収 集した。本検討では，この7段階のカテゴリー間には近似的 に心理的等間隔性が成り立っているものとして間隔尺度とし て扱っている。

\section{(2) 実験結果}

実験より得られたデータから 39 種類の印象語対間の相関 関係を見出し, それらの背後にある共通因子を探るために 因子分析を行った [7]. 因子負荷量の計算にあたっては相 関行列に対する固有值が 1.0 以上となる固有值を採り上げる こととし，共通因子数を 6 とした。第 1 因子が固有值 5.90 , 寄与率が $15.1 \%$, 第 2 因子が固有值 4.53 , 寄与率 $11.6 \%$, 第 3 因子が固有值 3.27 , 寄与率 $8.4 \%$, 第 4 因子が固有值 3.12 , 寄与率 $8.0 \%$, 第 5 因子が固有值 3.04 , 寄与率 $7.80 \%$, 第 6 因 子が固有值 2.06 , 寄与率 $5.28 \%$ となり, 累積寄与率が $56.2 \%$
表1 因子負荷量

\begin{tabular}{|c|c|c|c|c|c|c|}
\hline & 因子1 & 因子2 & 因子3 & 因子4 & 因子5 & 因子6 \\
\hline 圧倒される & 0.75 & 0.17 & 0.30 & -0.13 & -0.08 & 0.13 \\
\hline 迫カがある & 0.73 & 0.22 & -0.05 & 0.14 & 0.38 & -0.18 \\
\hline ダイナミックである & 0.72 & 0.17 & 0.09 & -0.14 & -0.17 & 0.12 \\
\hline 奥行きを感じる & 0.72 & -0.17 & 0.10 & 0.22 & 0.21 & -0.17 \\
\hline 曲のイメージが広がる & 0.55 & -0.06 & 0.35 & 0.00 & -0.38 & 0.10 \\
\hline 音が生々しい & 0.52 & 0.08 & 0.03 & 0.16 & 0.12 & -0.43 \\
\hline 広々としている & 0.51 & -0.01 & 0.08 & 0.46 & 0.07 & -0.06 \\
\hline 体が打ち震える & 0.13 & 0.79 & 0.16 & -0.29 & 0.17 & 0.16 \\
\hline 体の芯で感じる & -0.17 & 0.67 & 0.38 & 0.01 & 0.12 & -0.08 \\
\hline 内臓に染み入る & 0.13 & 0.64 & -0.06 & -0.03 & 0.16 & -0.12 \\
\hline 音に違和感がある & -0.13 & 0.63 & -0.24 & -0.07 & -0.26 & -0.01 \\
\hline 体で音楽を聴いている感じ & -0.05 & 0.55 & 0.52 & 0.08 & 0.26 & 0.01 \\
\hline 音が突き上げてくる & 0.21 & 0.50 & 0.10 & 0.05 & -0.15 & 0.23 \\
\hline スピート感がある & 0.00 & -0.54 & -0.06 & 0.06 & 0.18 & -0.14 \\
\hline 楽器に囲まれている感じ & 0.24 & 0.09 & 0.76 & -0.01 & -0.03 & 0.18 \\
\hline 音楽が自分を中心に広がってい & 0.07 & 0.00 & 0.74 & 0.04 & 0.02 & 0.23 \\
\hline 演奏者になった感じ & 0.02 & 0.20 & 0.65 & -0.13 & 0.37 & -0.18 \\
\hline 乗 り物で摇られているよう & 0.25 & -0.07 & 0.62 & -0.10 & 0.06 & 0.06 \\
\hline 自動演奏のギターのよう & 0.18 & 0.10 & 0.50 & 0.24 & -0.29 & -0.19 \\
\hline 繊細な & 0.19 & -0.24 & -0.04 & 0.73 & -0.04 & -0.13 \\
\hline 切れ味がある & 0.03 & -0.19 & -0.18 & 0.63 & 0.34 & 0.16 \\
\hline 音楽に集中できる & 0.22 & -0.15 & 0.02 & 0.60 & -0.09 & -0.05 \\
\hline リラックスできる & 0.00 & 0.03 & -0.37 & 0.52 & -0.28 & -0.01 \\
\hline ギターがわずらわしい & 0.18 & -0.18 & 0.00 & -0.51 & 0.09 & 0.08 \\
\hline 音が重い & 0.25 & 0.43 & -0.10 & -0.61 & -0.06 & -0.05 \\
\hline このスタイルに違和感がある & 0.07 & -0.21 & -0.19 & -0.64 & 0.04 & -0.30 \\
\hline 音割れがする & -0.01 & -0.03 & 0.07 & -0.47 & 0.74 & 0.04 \\
\hline 個 々の楽器の音が聴き取りやす & -0.18 & -0.09 & 0.02 & 0.04 & 0.66 & 0.07 \\
\hline 個々の楽器を意識する & 0.23 & -0.04 & 0.13 & -0.01 & 0.63 & 0.19 \\
\hline 踊りたい & -0.01 & 0.00 & 0.22 & 0.06 & 0.30 & 0.80 \\
\hline 眠気がなくなる & 0.05 & 0.27 & 0.03 & 0.07 & 0.20 & 0.75 \\
\hline 音が厚い & 0.42 & -0.11 & 0.43 & -0.28 & -0.04 & -0.49 \\
\hline 賑やな & 0.38 & -0.39 & 0.25 & -0.06 & 0.08 & 0.19 \\
\hline 乗りが良い & 0.39 & -0.30 & 0.34 & -0.02 & -0.16 & 0.31 \\
\hline 音が立体的である & -0.05 & 0.25 & -0.04 & 0.19 & 0.38 & -0.49 \\
\hline 音が近づく & 0.10 & 0.32 & 0.38 & 0.22 & 0.28 & -0.32 \\
\hline ギタ一以外の音が遠い & 0.07 & 0.33 & 0.21 & -0.25 & 0.45 & -0.01 \\
\hline スピーカ一が移動している & 0.25 & -0.16 & -0.31 & 0.08 & 0.39 & -0.35 \\
\hline 雾囲気の距離感が変わる & 0.40 & -0.12 & 0.29 & -0.21 & -0.30 & -0.28 \\
\hline
\end{tabular}

である，その後，バリマックスの直交回転を行い，因子負荷 量の絶対值が 0.50 以上の評価語対をグルーピングした因子 負荷量表を求めた。 その結果が表 1 である. 抽出された 6 個 の因子の命名は次のようにして行った。各因子において, 因子負荷量の絶対值が 0.7 超えるような印象語対を対象と して命名した。その結果,「因子 $1 」$ は, 圧倒される, 迫力 がある, ダイナミックな, 曲のイメージが広がる, といった 印象語の因子負荷量が大きく，「迫真感」因子と名づけた，

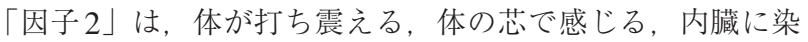
み入る，といった印象語の因子負荷量が大きく，「体感」 因子と名づけた。「因子 $3 」$ は, 楽器に囲まれている感じ, 音楽が自分を中心に広がっていく感じ, 演奏者になった感 じ，といった印象語の因子負荷量が大きく，「音像」因子と

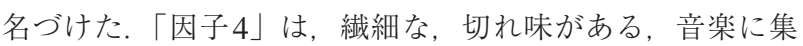
中できる，リラックスできる，といった印象と相関が高く, 「音楽の評価」因子と名づけた。「因子 5」は, 音割れがする, 個々の楽器の音が聴き取りやすい, 個々の楽器を意識する, といった印象語の因子負荷量が大きく,「音の質感」因子と 名づけた。最後に「因子 $6 」 は$, 踊りたい, 眠気が無くなる, といった印象語の因子負荷量が大きく，「体の反応」因子と 名づけた。

なお，ここではKJ法により質的に分類した項目と因子分 析により量的に分類した共通因子比較することを意図しては いないが, 結果的には因子分析で抽出された 6 個の共通因子 は, 前節の KJ 法で少人数によって直感的に分類された項目, すなわち, 音質, 音像, 体感, 音楽の䨌囲気, 聴取者の意識, ストレスとよく合致していることも付記しておく. 
このようにして，被験者が自由に記述した印象語を用いた $\mathrm{SD}$ 法による量的分析により, 提案している体感音楽聴取法 特有の印象構造を顕在化できたものと考えられる。

この中で，体感因子は体感音楽聴取時に特有な感覚であ り，他の共通因子とは独立して感じられるものとの結果に なっている，さらに，前節の質的分析で抽出された演奏者感 は，今までの音楽聴取法では得られなかった新たな感覚であ り，この感覚をもたらしている要因についても次のような結 果が得られている。すなわち, 演奏者感は, 体感因子の因子 負荷量が 0.2 と小さく，音像因子の因子負荷量が 0.65 と大き い結果になっている，すなわち，「演奏者になった感じ」と いう特有の感性は,「楽器に囲まれている感じがする」, 「音が自分中心に広がっていく感じがする」という印象から 得られるというとである。

次に，各楽曲を体感音楽聴取法で聴いたときの因子得点の 結果を図 4 に示す。プロットした点は属性別重心，すなわち 被験者全員の因子得点の重心を示している。

枯葉とカリフォルニアシャワーは，体感因子，音像因子と も得点が高い。すなわち，体感しながら演奏者感も強く受け ているという結果である。一方, Misirlouは体感因子, 音像 因子ともに得点が低い。アップテンポなロックミュージック であるが, 各楽器の音像の分離が明確でなくアップテンポ過 ぎたためであると考えられる。また，迫真感では枯葉と Misirlouが, 音の質感は枯葉とカリフォルニアシャワーの得 点が高くなっている.

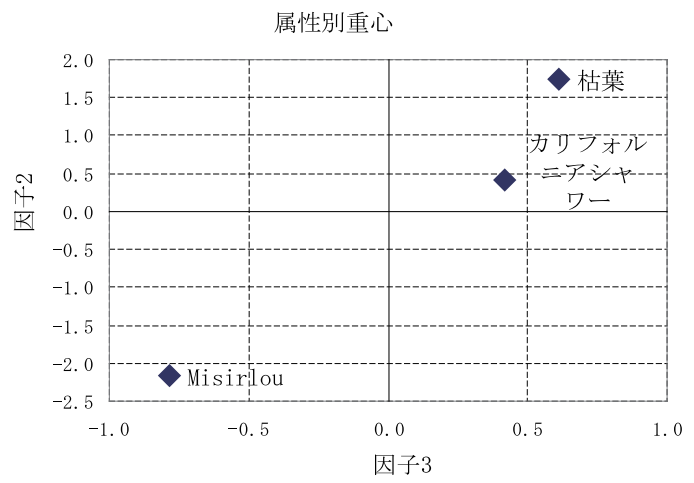

（1）体感因子と音像因子

属性別重心

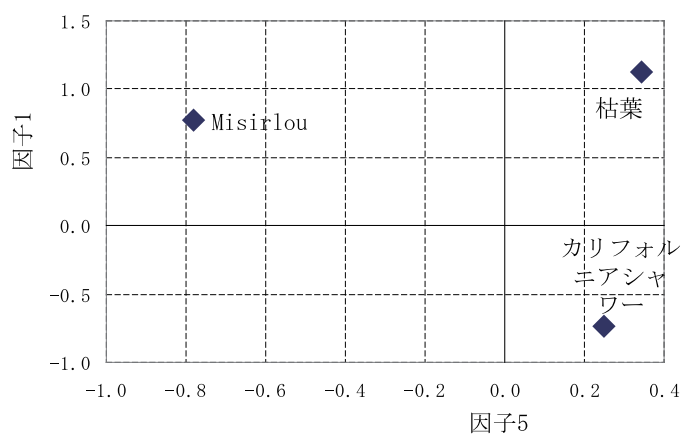

（2）迫真感因子と音の質感因子

図4 因子得点
以上，質的な分析手法で，我々が提案した体感音楽聴取方 法が固有に有している魅力と短所を網羅的に抽出し, その印 象空間を統計的な手法である因子分析で構築することができ た．さらに，この印象空間に被験曲をマッピングすることが できた，この結果は，様々な楽曲を，先の論文で述べた音楽 聴取の一般的な印象空間ではなく, 体感音楽德取法特有の印 象空間にマッピングし, 本聴取法の特徵を生かせる楽曲種類 を抽出できることを意味する。

それでも，まだ感性ロスは存在しているのではないかと考 えた，特に，質的分析で新たに抽出された「演奏者感」は新 たな音楽聴取コンセプトとして魅力が大きい. SD 法の結果 では，体感因子の因子負荷量は 0.2 と低い結果であったが, 感性口スの一つではないかと考え, 次節でさらに検討した。

\section{3. 演奏者感についての考察}

この体感音楽聴取法は, 他の音楽聴取法にない「演奏者に なったかのように音楽を聴取できる」という印象を質的デー タとして採取できた。前節の因子分析結果によると，演奏者 感は，「楽器に囲まれている感じがする」，「音が自分中心に 広がっていく感じがする」という音像因子の因子負荷量が大 きく，「体が打ち震える感じがする」や「体の芯で感じる」 といった体感因子の因子負荷量が小さいという分析結果であ る。つまり, 遠方音と特定楽器の至近音を融合すると演奏者 感が得られるという条件である。

我々は, 文献 [4]に拈いて, 至近音付与条件（開放型ヘッ ドホン使用, 体感デバイス使用) と演奏楽器種類（ベース, ドラム）を変えて「演奏者感」について一対比較法による比 較を行っている [7]。 その実験条件と比較結果を図 5 , 眓6

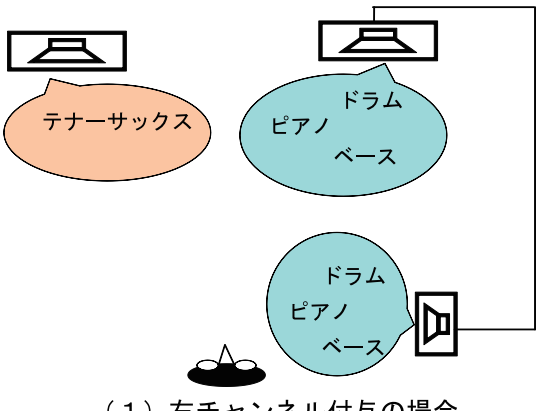

（1）右チャンネル付与の場合

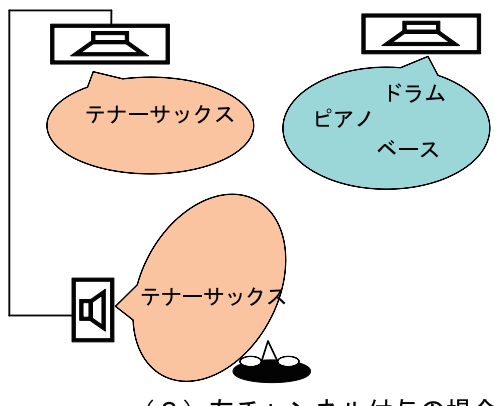

（2）左チャンネル付与の場合

図5 演奏者感についての評価実験 （文献 [4] の再掲） 


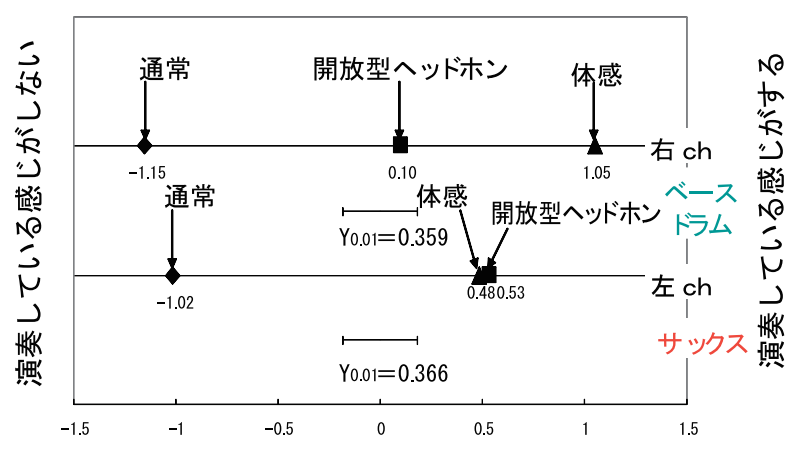

図6 演奏者感の比較結果 （文献 [4] の再掲）

に再掲している。この段階では，「演奏者感」を評価項目と したのは筆者の根拠のない想像によるものであり, 比較結果 は事実を示すに留まっていた。

今回の質的分析と量的分析による詳細な分析結果に基づい て, この実験結果を考察してみる.

この実験において, 開放型ヘッドホン聴取方法では, 開放 型ヘッドホンを右チャンネルに接続した場合は至近音として ベースやバスドラム音が耳付近から聴こえ, 左チャンネルに 接続した場合はテナーサックスの至近音が耳付近から聞こえ ることになる。一方, 体感音楽聴取方法においては, 体感入 ピーカを右チャンネルに接続した場合は, ベースやバスドラ ムの音が懐から聞こえるとともに振動を体前面で感じる。ま た左チャンネルに接続した場合は, テナーサックス音の振動 を感じることなく懷からの至近音を聞くことになる.

実験結果を見ると, 特定楽器が至近音として聞こえ, 他の 楽器が遠方音として聴こえる条件が「演奏者感」を増幅して いるという分析どおりの結果となっている. すなわち, 開放 型ヘッドホン，体感スピーカの両方とも「演奏者感」が得ら れている。しかし，詳細に見ると，テナーサックスの場合と ベース，ドラムの場合に違いが見られる。ベース，ドラムの 場合, 開放型ヘッドホンによる至近音より体感スピーカの方 がさらに「演奏者感」を増幅している，開放型ヘッドホンに よる至近音との違いは, 懷から音が聞こえることと振動触覚 による体感があることである，この結果は，懐から音が聞こ えることが演奏者感の取得に支配的であれば, 前節の結果通 り音像因子が寄与しており, 耳元より聴こえる開放型ヘッド ホンに比べて演奏者感が増幅するものと理解できる.

さらに, 体感スピーカーで得られた振動触覚については, 「体感因子」は演奏者感と相関が低いという前節の結果に基 づけば演奏者感には寄与していないと推測される。しかし, 筆者らはこの点に疑問を感じている。 ここで与えられた振動 触覚が, 因子分析で得られた「体感因子」とは異なる種類の 感性を与えているのではないかということである.すなわ ち，「指先で感じられる振動が弦に触れているようである」 とか,「スティックに伝わる振動を感じているようだ」といっ た物理的なリアクションから得られる感性が存在し, この感
性も演奏者感を感じさせる要因になっている可能性が考えら れる.

そうであれば，今回の被験者が自由に記述した印象語を用 いた因子分析では取り逃がした感性ということになる，その 原因は，最初に採集した印象語の中に，この印象が入ってい なかったためである。

ただし, 被験者が自由に記述した印象語によるKJ法では, この感性は，実験担当者がごく自然に発想して文章化した内 容には反映されている.

\section{4. ま と め}

筆者等が提案している体感音楽聴取法について, 量的分析 だけでは，本質的な魅力と具体的な設計に結びつく知見が得 られなかった。 そこで, ギターやべース，バスドラムといっ た振動を抽出しやすい楽曲に限られるが, 質的分析を重視し つつ量的分析を組み合わせた方法で再度評価した。なお，本 研究において, 被験者は音楽経験, 楽器への興味関心·習熟 度は不問とした。

まず, 被験者に通常のステレオ音楽聴取法と体感音楽聴取 法の両方で被験曲を聴いてもらい, 体感音楽聴取法による音 楽聴取時の生の印象を広範に採集し, 得られた印象語を $\mathrm{KJ}$ 法を用いて分類整理した。 その結果，筆者らが提案している 体感音楽聴取法特有の魅力と課題が顕在化し，しかもその特 徵が体系的に整理された。

次に，質的分析に用いられた被験者が自由に記述した印象 語から印象語対を作成し, SD法による主観評価を実施した。

その結果, 体感音楽聴取法独自の印象構造を深く掘り下げ ることができ, オーソドックスな SD法と因子分析で抜け落 ちた本体感音楽聴取法の魅力と展開すべき課題が明らかに なったと考えられる，特に，体感音楽聴取時に特有な感覚で あり，他の共通因子とは独立して感じられる体感因子および 音像因子が抽出されている。 さらに, 体感音楽聴取法特有の 印象として採取された演奏者感は, 音像因子の因子負荷量が 大きいという結果が得られた。

なお，演奏者感については，さらに体感因子との関連につ いて検討を行った。体感因子の因子負荷量が小さいという今 回の結果は, 感性ロスが生じたものと考えられる。「演奏者 感」が触覚刺激で増大しているという前論文の結果と矛盾す るからである。被験者が自由に記述した印象語の取得の段階 で, 指先の触覚刺激から受ける印象を取りこぼしたことに起 因していると思われる。ただし，KJ法による文章化におい ては, 振動触覚により演奏者感が得られていると直感により 記述されていることは大変興味深い.

結論としては, 質的分析と量的分析をお互いを補完し合い ながら, 筆者等が提案する体感音楽聴取法の魅力の伝達と設 計指針につながる評価ができたのではないかと考える。

今後は, 楽器種別と楽曲種別の分類を幅広く行い, それぞ れに㧍ける体感音楽聴取法の魅力と課題の抽出を, 今回のよ うに質的分析と量的分析を組み合わせて実施していきたい. 


\section{参 考 文 献}

［1］井手口健, 熊田信義, 永野秀和：印象強調を目的とした音 楽聴取時の振動付与方法の検討, 感性工学研究論文集, Vol.3, No.1, pp.53-62, 2004.

[2] 永野秀和, 井手口健, 畑地洋彦: アコースティックギター を用いた音楽の体感聴取方法の検討, 電子情報通信学会論 文誌A，Vol.J87-A，No.11，pp.1460-1465， 2004.

[3] 井手口健, 村中将人：ステレオ音源を用いた体感音楽聴 取方法の感性増幅効果, 日本感性工学会研究論文集,

Vol.7, No.1, pp.111-118, 2007.

[4] Tsuyoshi Ideguchi, Masato Muranaka; Influence of the sensation of vibration on perception and sensibility while listening to music, IJICIC Vol.5, No.3, pp.631-640, March 2009.

[5] 椎塚久雄：定量的な感性評価で失われたものはどこで補う のか, 感性工学, Vol.10, No.4, pp.210-218, 2011.

[6] 川喜田二郎：続·発想法 $\mathrm{KJ}$ 法の展開と応用, 中公新書, 1970 年 2 月.

[7] 新版官能検査ハンドブック，日科技連，1973.

[8］岩宮眞一郎：音楽と映像のマルチモーダル・コミュニケー ション, 九州大学出版会, pp.19-49, 2000.

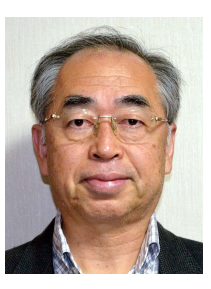

\section{井手口 健（正会員）}

1971年九州大学工学部通信工学科卒業. 同年 日本電信電話公社 (現NTT) 入社. 1996年 九州東海大学工学部電子情報工学科 教授に転職. 現在, 東海大学産業工学部電 子知能システム工学科教授. この間, 電磁 環境の評価・対策技術の研究および感性工学の研究に従事. 博士 (工学). IEEE EMCソサエティ (シニア会員), 電子情報 通信学会, 日本感性工学会会員. 